\title{
НОВЫЕ АСПЕКТЫ В КОМПЛЕКСЕ ПАРАЗИТОВ ЧЕШУЕКРЫЛЫХ ВРЕДИТЕЛЕЙ СЛИВЫ И ЭТОЛОГИИ СЛИВОВОЙ ТОЛСТОНОЖКИ
}

\author{
Иордосопол Е. И., Маевски В. П.
}

Институт генетики, физиологии и защиты растений, Кишинев, Республика Молдова. e-mail: iordosopol@yahoo.com

https://doi.org/10.53040/9789975347204.12

Abstract: This work contains information on the role of nectar-bearing grasses in attracting parasites of the main plum pests, their localization and the formation of entomological microreserves, comparing it with the seasonal dynamics of the number of the main plum pests Grapholitha funebrana Tr, G. molestae B, Anarsia lineatela L.

On the ethological aspects of the stone fruit pest of the plum Eurytoma schreneri $\mathrm{S}$. in comparison to different varieties of plum.

Keywords: nectar-bearing grasses, parasites, plum pests, ethological aspects.

\section{Введение}

Из нектароносных растений на сливе в международной практике испытывались аллисум, райграс, овсяницу, мятлик, и белую горчицу. Раннее на яблоне в нашем 
институте были испытаны фенхель, фацелия, укроп и гречиха. Установлено, что весенний посев нектароносных трав обеспечивает прикрытие тех периодов, когда природный конвейер довольно скуден из-за погодных условий (температура и влажность), а также уничтожения травостоя при культивация междурядий и укосах между деревьями, а осенний посев обеспечивает на следующий год весенний комплекс паразитов дополнительным питанием. В работе Коренева А. (1989), описан энтомологический комплекс нектароносных трав на яблоне, распределяя их по группам, где - 90 \% фитофагов нектароносов служат как добавочные хозяева для вредителей плодоносных деревьев, $10 \%$ проводят часть жизни в кроне деревьев (цикады и др.) и вредители плодовых культурных - единичные. Распределил и энтомофагов по 3-м группам, где 80\% составляют полифаги (акарифаги, афидофаги), $10-15 \%$ составили олигофаги, паразитирующих на вредителей нектароносов.

Цель исследования состояла в оценке нектароносных смесей по количествнному и качественному привлечению паразитов и хищников на всех стадиях развития плодожорок Grapholitha funebrana $\mathrm{Tr}$, G. molestae B, моли Anarsia lineatela L. и сливовой толстоножки Eurytoma schreneri S.

\section{Материалы и методы}

Для выявления вредителей, зимующих видов энтомофауны в почве, были проведены раскопки под 8 учетными деревьями позднеспелого сорта сливы Анжелино и Стенлей на глубине $45 \mathrm{~cm}$, размером 0,25 м². Численность толстоножки определяли по анализу собранных косточек (1000 шт.). Сезонные колебания численности паразитов и фитофагов, привлеченных нектароносными смесями, определяли путем анализа отлова на 160 желтых клеевых ловушек и кошением энтомологическим сачком. Мониторинг чешуекрылых провели с помощью феромонных ловушек. В опыте смеси нектароносных трав распределили стандартным методом в 3 вариантах с контролем, в 4 повторениях, в 4x междурядьях второго года плодоношения. Эффективность испытанной смеси сравнивали с природным контролем.

\section{Результаты и обсуждения}

Год 2018 был засушливым для центральной зоны Республики Молдова и способствовал развитию вредителей сливы. Среди них отмечены активность одной из 3 видов вредны чешуекрыльх на сливе, это фруктовая полосатая моль, обнаружунную во время выдвижения и распускания почек. Бабочки первой генерации появились в конце II-ой декады мая при температуре $21^{\circ} \mathrm{C}$ и влажности воздуха $61 \%$, по 9 отловленных особей на феромонную ловушку, а с началом II-ой декады июля отмечено постепенное ее снижение. Вторая генерация - с конца II-ой декады июля по началу I-ой декады сентября, но с былее низкой численностью, при этом, поврежденность побегов и фруктов - незначительная.

Первая генерация сливовой плодожорки появилась с 22 апреля по 21 июня месяца в среднем 149 особ. /лов. В динамике лета самцов на ловушку отмечено 2 пика (I-ый с

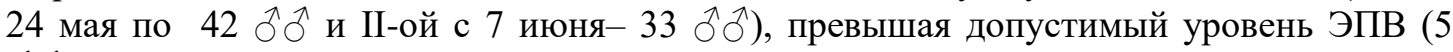

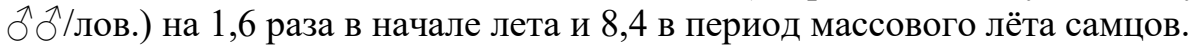

Вторая генерация сливовой плодожорки длилась с 28 июня по 23 августа и была относительно однородной , при этом в начале II-ой декады августа численность отловленных самцов снизилось в 3 , а в середине декады в 5 раз. В целом, отлов самцов на ловушку во второй генерации был в 1,7 раза ниже, чем в первой генерации. С III-ей декады августа отмечено по $20 \hat{\jmath} /$ /ловушку. Вероятнее всего, это часть гусениц со 
второй генерации которые ушли в летнюю диапаузу последними и их воспринимают как третью факультативную генерацию.

По фенологии вредителя, в фазе яйца (II-я декада мая - III-я декада июня) из яйцеедов, на нектароносные травы, отмечены Trichogramma evanescens, Ascogaster rufidens и хищный трипс Aeolothrips intermedius. В фазе гусениц (III-я дек. V по II-ой дек. Vii) на нектароносы встречались виды из семейств PTEROMALIDAE EULOPHIIDAE и Chrysopa carnea, в фазе куколки (II-я декада июня по III-ей декаде августа) на нектароносов - также отмечены виды птеромалид и эвлофиид.

Лёт восточной плодожорки в первой генерации наблюдали с 22 апреля по 17 июня - 57 дней, по 58 ふぶлов., вторая - с 21 июня по 27 июля - по 36 ふふ лов. , третья с 27 июля по 06 сентября - по 40 ふ઼ふ лов. и четвертая - с 06 сентября по 28 сентября -

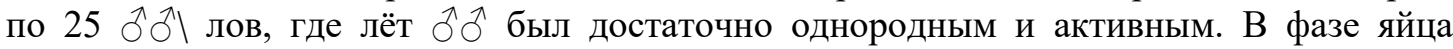
вредителя, во всех 4 генерациях на нектароносы питались одновременно виды энтомофагов такие как Trichogramma pallida (TRICHOGRAMATIDAE) и Ascogaster quadridentata (BRACONIDAE), что было учтено и в клеевых ловушках. На фазе гусеницы - в первые наблюдали отмечены виды Elasmus albipennis (EULOPHIIDAE) и Atanycolus sp. (BRACONIDAE).

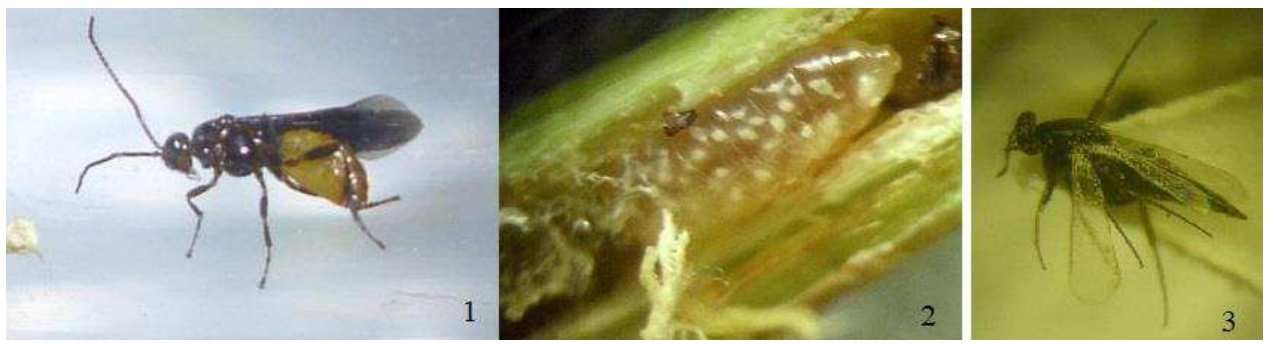

Рис.1. (ориг.). Паразиты восточной плодожорки: 1- самка браконида Atanycolus sp.; 2личинка браконида в побеге; 3- самка эвлофиида Elasmus albipennis

В фазе куколки на нектароносах - Dybrachis affinis и D. cavus cavus (PTEROMALIDAE), а в клеевых ловушках-Pediobius pyrgo (EULOPHIIDAE). Из паразитов отловленных сачком на нектароносах встречались Diadema armilata, Trichogramma evanescens и оба вида дибрахиса. Из паразитов сем. ICHNEUMONIDAE на нектароносах отмечены Polyblastus macrocentrus, Lathrostizus macrostoma, из BRACONIDAE, Bracon variator, на клеевые ловушки - A. quadridentata. Сливовая толстоножка (Eurytoта schreineri (amygdali) отмечена с высоким процентом поражения плодов. Отмечено расхождение в биологии данного вида из-за того что способ прокола на плоды разные на сортах Анжелино и Стенлей, На сорте Стенлей личинка подает с фруктами, а на Анжелино он остаются на 70\% в собранном урожае.
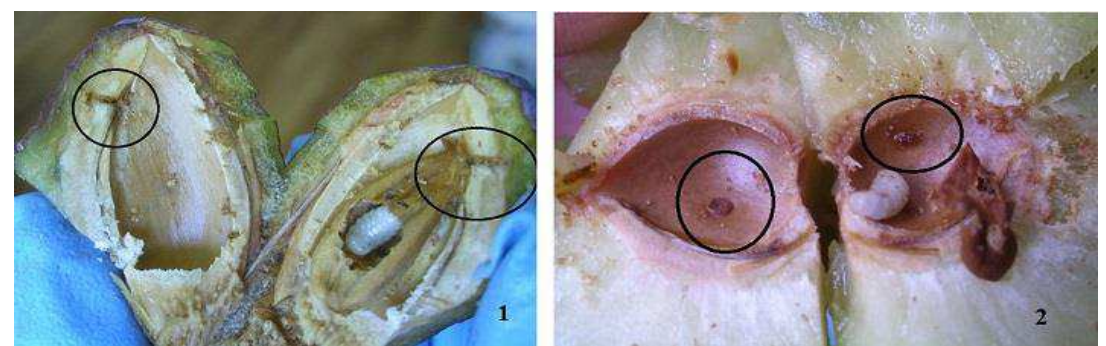

Рис. 2. Проколы толстоножек: 1- одиночный прокол на Стенлей и 2 - двойной на Анжелино. 
Знаком и тот факт что абрикос и сливу повреждает еще приморская (E. maslovskii) и азиатско-индийская толстоножка (E. samsonovi). Не исключено, что имеет место быть другой вид толстоножки, для этого надо вывести взрослых особей и провести их определение. Из ее паразитов на нектароносах питались виды из сем. EUPELMIDAE, Macroneura falcata, Eupelmus atropurpureum и сем. PTEROMALIDAE - Leptomeraporus nicare.

Данные, полученные посредством желтыми клеевыми ловушками, показали присутствие паразитов и хищников непосредственно в кроне деревьев на протяжение всего вегетационного периода в соотношении хищник/фитофаг- 1:1,5 и паразит/ фитофаг- 1:3.

При анализе показателей наблюдали разницу по фазам развития нектароносов в тестируемом варианте, эталонах и контроле с соотношением фитофаг/полезные насекомые в кроне сливы 1:3.

\section{Выводы}

Тестируемый вариант нектароносных трав привлекает 9 семейств паразитов яйц, гусениц и куколок чешуекрылых вредителей сливы. Данная смесь имеет продолжительный срок цветения с первой декады июня по третьей декады августа.

Установлено, что численность фитофагов в кроне сливы на фоне нектароносов снизилось в 2 раза по сравнению с контролем.

Выявлены два новых вида паразитов для восточной плодожорки.

Отмечено на сливе два типа прокола плодов сливовой толстоножкой, что можно предположить и о существовании нового вида толстоножки на сливе в нашем регионе.

\section{Библиография}

1. Iordosopol, E. Batco, M. Eliseev, S. 2018 Influiența mixurilor nectarifere asupra insectelor benefice, prădători și paraziți ai moliei orientale și moliei prunului / În: Simpozium ştiinţific international „Agricultura modernă-realizări şi perspective” 80 ani de la fondare, 4-6 octombrie, Volum 47, p. 605-609. ISBN 978-9975-64-296-5.

2. Iordosopol E., Iachimciuc A. 2015. Dinamica atacului lăstarilor de Grapholita molesta Busck., Anarsia lineatella L. la cultura piersicului și atracția paraziților lor de mixtura de plante nectarifere. Materialele simpozionului Internațional „Horticultura modernă realizări și perspective”, Lucrări științifice Vol. 42., Chișinău, 1-2 octombrie, 359-364. ISBN 978-9975-64-248-4.

3. Iordosopol, E. Iachimciuc, A. Batco, M. et al. 2014. Eficiența amestecului de plante nectarifere în diminuarea numerică a dăunătorilor sugători la piersic. Materialele "Genetica, fiziologia și ameliorarea plantelor “. Conferință științifică internațională, (5; Chișinău ). 363367. ISSN 978-9975-56-194-5.

5. Якимчук, А. П. Иордосопол, Е. И. Дюрич, Г. Ф. 2012. Привлечение энтомоакарифагов нектароносными травами. /Материалы докладов Международного симпозиума «Зашита растений - проблемы и перспективы», 30-31 октябрь, Кишинев. Информационный бюллетень ВПРС МОББ № 41, Стр. 83-86. ISBN 978-9975-56-069-6.

6. Iordosopol, E. Iachimciuc, A. Batco, M. 2011. Rolul plantelor nectarifere în păstrarea şi menţinerea paraziţilor viermelui mărului, moliei orientale, afidelor şi a entomoacarifagilor. În mat.: Simpozionul ştiinţific internaţional "Rezervaţia Codrii - 40 ani" Lozova, 29-30 septembrie, pag. 191-193. ISBN 978-9975-67-799-8.

8. Коренев, А. А. 1989. Структура энтомокомплекса нектароносных трав в яблоневом саду. / в кн. Фауна антропогеного ландшафта Молдавии. Кишинев 
«Штиинца», тез. Докл. Респ. Науч. Конф. «Проблемы управления и конструирования фаунистических комплексов в антропогеном ландшафте Молдавии». Стр. 55-56. 